This is the accepted version of a forthcoming article that will be published by Sage in Journal of Environment and Development: http://journals.sagepub.com/loi/jeda

Accepted version downloaded from SOAS Research Online under licence CC-BY-NC 4.0 International from:

http://eprints.soas.ac.uk/24930/

\title{
The prospects, politics and practices of solar energy innovation in China
}

Frauke Urban, SOAS University of London

Yu Wang, Tsinghua University

Sam Geall, University of Sussex

\begin{abstract}
:
This paper examines the prospects of, and politics and practices around, solar energy in China. It examines two different solar energy technologies, namely solar photovoltaic (PV) and solar water heaters $(\mathrm{SWH})$, in order to understand how different pathways for low carbon innovation are supported and constrained by (the lack of) political support at the national and local level, the interactions between state and non-state actors, as well as how they relate to changing practices among consumers. The paper also discusses obstacles and trade-offs. We find two very different approaches to solar energy. The solar PV industry in China is experiencing increased domestic growth, after many years of being mainly export-oriented. Prices declined rapidly in recent years, and solar PV also enjoys much political and financial support from the central government and local governments. However there are high bureaucratic and technical hurdles to get grid connected and access the feed- in-tariff, particularly for individual users. Solar water heaters on the other side are a 'home grown' Chinese technology that is ubiquitous in China, particularly in rural areas, easy to install and use, and that has developed from the grass-roots levels to mass products with relatively little government support. Although being largely neglected by high-level discussions and plans, SWH could contribute much to low carbon transitions that are driven at the local level in China.
\end{abstract}

\section{Introduction}

China is often considered a leader in the green economy. No other country invests more in renewable energy than China, including in solar energy. Solar energy is important as an alternative source of energy as about $80 \%$ of the global primary energy supply comes from fossil fuels, primarily oil and coal (IEA, 2017).

Energy use, energy production and $\mathrm{CO}_{2}$ emissions have increased rapidly in China since the beginning of its economic reforms around three decades ago. Furthermore, while China had low per capita energy use and emissions for a long time the country has been catching up in recent years. China's per capita $\mathrm{CO}_{2}$ emissions are today comparable with those of the European Union (World Bank, 2017; IEA, 2017). China is also the world's largest energy user and absolute $\mathrm{CO}_{2}$ emitter (IEA, 2017) and it may lead on cumulative emissions within 10 to 20 years (Stavins, 2014).

At the same time, China has also become a world leader in renewable energy, most notably in wind energy, solar energy -both solar photovoltaic (PV) and solar water heaters (SWH)- and hydropower. China tops the renewable energy field globally in terms of investments, 
This is the accepted version of a forthcoming article that will be published by Sage in Journal of Environment and Development: http://journals.sagepub.com/loi/jeda

Accepted version downloaded from SOAS Research Online under licence CC-BY-NC 4.0 International from: http://eprints.soas.ac.uk/24930/

production and installed capacity (IEA, 2017). China invested nearly US\$90 billion in renewable energy in 2012 (Bloomberg, 2013) and this is estimated to increase to more than US $\$ 360$ billion per year by 2020 (Reuters, 2017).

This paper examines the prospects of, and the politics and practices around, the green economy ${ }^{1}$ in China, drawing on a case study from solar energy innovation. It examines two different solar energy technologies, namely solar PV and SWH. The paper investigates two case studies in order to understand how different pathways for low carbon innovation are supported and constrained by (the lack of) political support at the national and local level, the interactions between state and non-state actors, as well as how they relate to changing practices among consumers. This paper also discusses how these two technologies could contribute to national climate and energy targets, what obstacles and trade-offs are occurring and how they are dealt with. This is in line with the special issue which addresses transitions to the green economy in the Global South.

The paper finds two very different approaches to solar energy. The solar PV industry in China is experiencing increased domestic growth, after many years of being mainly export- oriented. Prices declined rapidly in recent years, and solar PV also enjoys much political and financial support from the central government and local governments. However there are high bureaucratic and technical hurdles to get grid connected and access the feed-in-tariff, particularly for individual users. Solar water heaters on the other side are a 'home grown' Chinese technology that is ubiquitous in China, particularly in rural areas, easy to install and use, and that has developed from the grass-roots levels to mass products with relatively little government support. Although being largely neglected by high-level discussions and plans, SWH could contribute much to low carbon transitions that are driven at the local level in China.

Section 2 presents the conceptual framework and methods, section 3 presents the findings, section 4 discussion and conclusion.

\section{Conceptualising the green economy in China}

\subsection{The Chinese state and energy politics}

\section{Role of the state}

Lederer, Wallbott, \& Bauer (forthcoming) suggest that research on the role of the state on environmental issues in the Global South is rare. Exceptions are the analysis of the effectiveness of environmental authoritarianism as a way to reach environmental targets (Wurster, 2013; Beeson, 2010; Gilley, 2012; Schreurs, 2011; Held, Roger \& Nag, 2013).

This paper addresses China's changing policy-making setting in relation to solar energy, elaborating whether and how the state plays a pro-active role in the solar energy industry

\footnotetext{
${ }^{1}$ Green economy (GE) is here defined as an economy "that results 'in improved human well-being and social equity, while significantly reducing environmental risks and ecological scarcities. In its simplest expression, a GE is low carbon, resource efficient, and socially inclusive" (UNEP, 2011, p. 16).
} 
This is the accepted version of a forthcoming article that will be published by Sage in Journal of Environment and Development: http://journals.sagepub.com/loi/jeda

Accepted version downloaded from SOAS Research Online under licence CC-BY-NC 4.0 International from: http://eprints.soas.ac.uk/24930/

and at what level (e.g. central, provincial, municipal government). Policy-making has changed considerably since the last change in leadership in China, for example with the introduction of the $13^{\text {th }}$ Five Year Plan for the period 2016-2020 and the introduction of the "new normal" of lower economic growth followed by economic restructuring and redistribution of wealth.

The paper also explores whether and to which extent the state takes a pro-active role in the solar energy industry in China. This research is interested in the scale and scope of the proactive state in the solar energy industry, for example by examining how the state is directly involved through state-owned enterprises (SOEs), as well as strong policy and financial support for its industries. China's state can therefore be described as a pro-active state, as opposed to an inactive state or a laggard (see also Lederer, Wallbott, \& Bauer (forthcoming)).

However, China's 'fragmented authoritarianism' (Lema \& Ruby, 2007) and the power struggles between the central and provincial / municipal governments characterises the way the state deals with energy issues. Different ministries within central government have different roles, motives, interests and approaches towards solar energy, such as the Ministry of Environment (MEP) which has environmental protection as its main goal, the Ministry of Science and Technology (MOST) which is interested in innovation and scientific development - including in the fossil fuel field, the Ministry of Commerce (MOFCOM) which is interested in international trading and cooperation. See also figure 2. There is further a discrepancy between the interests of the local (provincial / municipal) government and the central government. The local governments are subjected to legislation and executive orders from the central government, however the local governments have the power to implement these using their own interpretation. This may mean that the local government may be more lenient or stringent than advised by central government; or they may adopt more of a tick- box exercise by using creative accounting rather than implementing large-scale change. There is a saying in China that the further the local government is away from Beijing, the less stringent the implementation of legislation and orders may be. Evidence of fragmented authoritarianism for low carbon energy technology development in China has been discussed by Lewis (2013), Wang \& Liu (2017) and Gilley (2017) and this literature suggests that there is a stronger need to integrate politics, policy and administration.

\section{Innovation in low carbon energy technology}

In recent years a large body of literature on innovation in low carbon technology and its links to international development has emerged (e.g. Ockwell \& Mallett, 2012; Watson, Byrne, Ockwell \& Stua, 2014). China is often regarded as being in an exceptional position to become a global leader of the low carbon transition: China's government is actively pursuing low carbon development strategies, including building up the innovative capacity of key firms; it has made large sums of state capital available for low carbon industries and pursues various strategies of accessing the latest low carbon technologies.

Low carbon innovation - creating and bringing to market new products, services or ideas that reduce greenhouse gas emissions - is crucial to achieving low carbon energy transitions and thus mitigating climate change. The diffusion of low carbon innovation is a complex process, which includes research, development, demonstration and deployment (Watson, 2008), and is not only a technological process. It also depends on the existence of 
This is the accepted version of a forthcoming article that will be published by Sage in Journal of Environment and Development: http://journals.sagepub.com/loi/jeda

Accepted version downloaded from SOAS Research Online under licence CC-BY-NC 4.0 International from: http://eprints.soas.ac.uk/24930/

appropriate policy support and incentives for firms and other organisations to engage in technological development, for the creation of markets for technologies that are successfully commercialised as well as skilled labour, including highly trained engineers and technicians, and therefore involves a wide range of actors including firms, public bodies, and research organisations (Ockwell \& Mallet, 2012; Saviotti, 2005).

Historically, low and middle-income countries, including China, have depended to a large extent on international technology transfer and cooperation from high-income countries for some low carbon technologies, but over the decades, Chinese firms have built up their own productive capabilities as well as their own innovative capabilities (Urban, 2018). 'Indigenous innovation', according to its typical Western definition, means that a particular country's firms or institutions have invented, conceptualised or built a particular innovation. From a Chinese perspective, indigenous innovation can also be based on foreign knowledge, experience, staff, networks and technology acquired from and/or licenced by Chinese firms or through reverse engineering based on foreign technology. These differences in understanding have caused frictions around intellectual property rights (IPRs) in the past.

In recent years, various forms of technology cooperation such as networking, staff exchange schemes, joint ventures, licencing, mergers and acquisitions have played a larger role and indigenous innovation has become more prevalent (Urban, 2018). This is particularly relevant for $\mathrm{SWH}$, since China uses a technology that is different to those in many other countries, and Chinese firms hold most of the SWH patents worldwide. There is also process innovation in the Chinese PV sector (Zhang \& Sims Gallagher, 2016), although in the past an exchange of knowledge, experience, staff and networks in a globalised market played a role for the development of the Chinese market.

\subsection{Methodology}

This paper is based on a study of solar energy in China, with specific focus on the different pathways for solar PV and SWH. It follows a case study methodology based on Yin (2003). Following Miles \& Huberman (1994), our case selection criteria consider the significance of the case, its representativeness, its theoretical relevance, and data accessibility. Solar PV and SWH are significant, because they are the most market-ready and commercialised solar technologies in China. They are representative as they are used everywhere in China. This case is theoretically relevant as we examine the prospects, politics and practices of these technologies, hence socio-political issues that tend to be less discussed in low carbon innovation studies for China. Finally, data is accessible as the study draws on a large number of materials used, including data from the Chinese Statistical Yearbooks, the IEA, the World Bank, a wide range of policy documents and academic literature published in journals, books and working papers.

The empirical research conducted for this paper includes in-depths interviews and focus group discussions, as well as site visits. 27 semi-structured, in-depth interviews were conducted in China with (solar) energy experts from research and academia, representatives from solar energy firms and business associations, representatives from government authorities at various levels and representatives from Non-Governmental Organisations (NGOs), as well as 6 focus group discussions (FGDs) with groups of users of solar energy 
This is the accepted version of a forthcoming article that will be published by Sage in Journal of Environment and Development: http://journals.sagepub.com/loi/jeda

Accepted version downloaded from SOAS Research Online under licence CC-BY-NC 4.0 International from: http://eprints.soas.ac.uk/24930/

and with solar energy firms in Beijing, Dezhou and Yingkou. In addition, several site visits were conducted to leading solar energy firms which showed us their solar production lines, their trade exhibitions as well as ground-mounted solar PV farms. The fieldwork was conducted between 2014 and 2016 in Beijing, Dezhou, Tianjin, Baoding and Shanghai. The selected firms include China's leading solar firms, business associations, government authorities, experts and academics and representatives. Interviewees were senior managers, experts or project leaders with substantial knowledge in solar energy issues in China. See table 1 for more details.

Table 1: overview of the interviewees and their affiliations

\begin{tabular}{|l|l|}
\hline $\begin{array}{l}\text { Sector and number of } \\
\text { interviews }\end{array}$ & Affiliation of interviewees \\
\hline $\begin{array}{l}\text { Solar PV: 27 interviews, } \\
\text { FGD with users }\end{array}$ & $\begin{array}{l}\text { Firms like Yingli Solar, Trina Solar, JA Solar, Jinko Solar, Hanergy, } \\
\text { Himin (known as Huanming in China), several smaller solar energy } \\
\text { firms }\end{array}$ \\
\hline & $\begin{array}{l}\text { Business associations like China National Renewable Energy Centre, } \\
\text { Beijing Energy Association }\end{array}$ \\
\hline $\begin{array}{l}\text { Government agencies like National Development Reform Commission } \\
\text { (NDRC), provincial Development Reform Commissions (DRC), Ministry } \\
\text { for Science and Technology (MOST), Ministry of Commerce } \\
\text { (MOFCOM) }\end{array}$ \\
\hline $\begin{array}{l}\text { Research institutes like Tsinghua University in Beijing, Tianjin University } \\
\text { of Technology, Zhejiang University, Peking University, Hunan University, } \\
\text { Shanghai University, Fudan University, NDRC's Energy Research } \\
\text { Institute (ERI), Chinese Academy of Sciences (CAS) }\end{array}$ \\
\hline $\begin{array}{l}\text { NGOs like Greenpeace, the Natural Resources Defence Council } \\
\text { NRDC, Greenovation Hub }\end{array}$ \\
\hline
\end{tabular}

\section{Findings: solar energy in China}

China is now not only the world's largest investor and producer of solar PV modules and SWH systems, but China also has the world's largest installed capacity of SWH (REN21, 2017). Solar PV and SWH have different technological, economic and social characteristics and dynamics: solar PV is usually more expensive, higher tech and, unlike $\mathrm{SWH}$, needs integration with the electricity grid; PV also needs to overcome higher barriers related to IPRs on key upstream technologies (see Table 2 for a rough summary of these different dynamics, technologies and innovation pathways).

Table 2: Key differences in solar PV and SWH

\begin{tabular}{|l|l|}
\hline Solar PV & Solar water heaters \\
\hline Higher tech due to systems integration with grid & Lower tech due to stand-alone system \\
\hline Partly dependent on tech / knowledge transfer & Indigenous innovation \\
\hline High IP barriers & Lower IP barriers \\
\hline Higher cost & Lower cost \\
\hline More centralised due to integration with grid & Decentralised \\
\hline $\begin{array}{l}\text { Export-oriented, although strong increase in } \\
\text { domestic demand in recent years }\end{array}$ & Domestically-oriented \\
\hline
\end{tabular}


This is the accepted version of a forthcoming article that will be published by Sage in Journal of Environment and Development: http://journals.sagepub.com/loi/jeda

Accepted version downloaded from SOAS Research Online under licence CC-BY-NC 4.0 International from: http://eprints.soas.ac.uk/24930/

Figure 2 provides an overview of the actors involved in the policy-industry-society interactions in the solar energy sector, including their relationships and flows of influence. Key players are the National Development and Reform Commission NDRC, the Ministry of Science and Technology MOST, the Ministry of Environmental Protection MEP, the Ministry of Finance MOF, the Ministry of Industry and Information Technology MIIT, the Ministry of Commerce MOFCOM, the Ministry of Foreign Affairs MOFA.

Figure 2: Actor mapping for the policy-industry-society interactions in the solar energy sector and their relationships and influence.

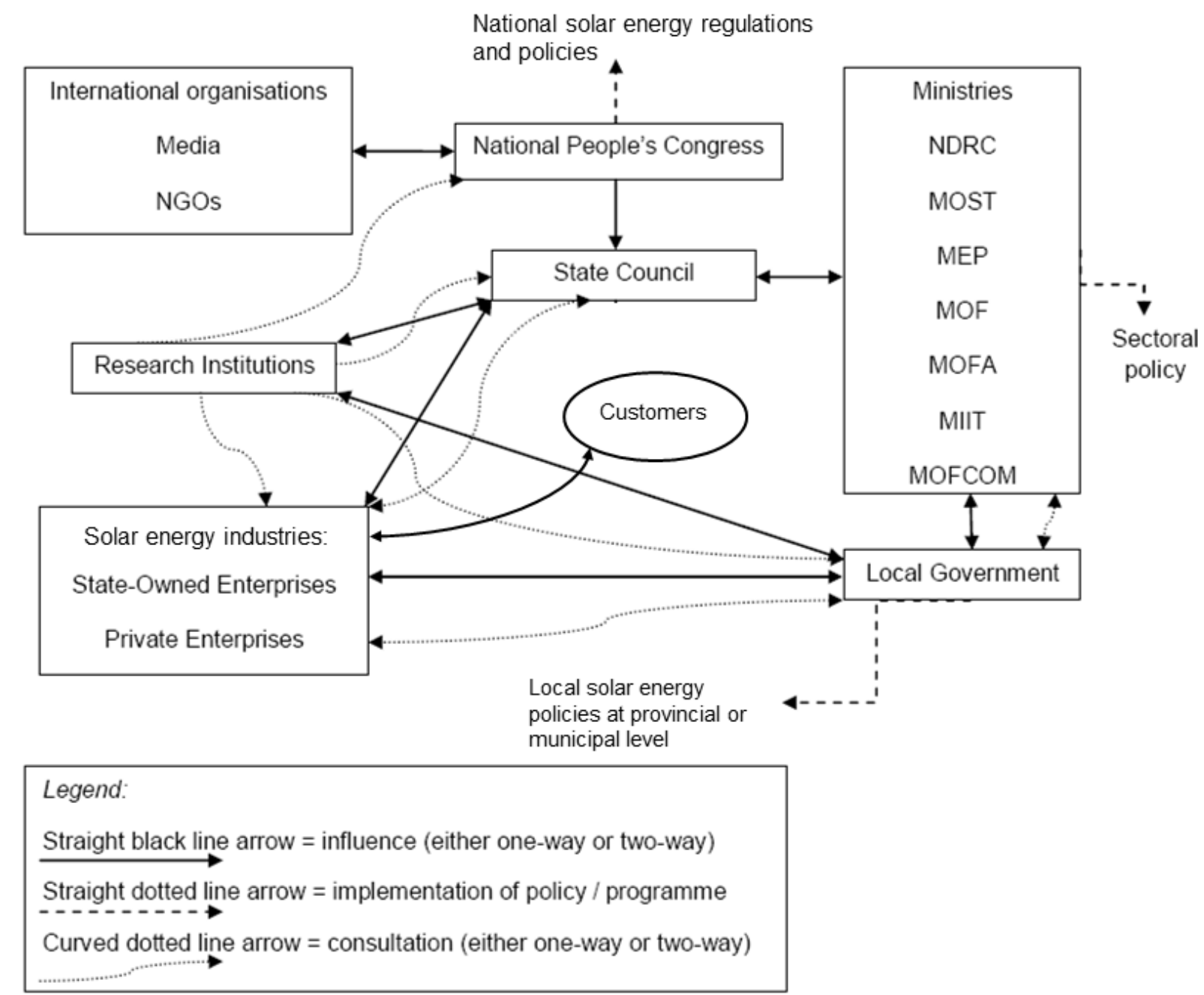

Data source: Interviews with government, industry, research institutions, NGOs and solar energy users, 2014-2016. Amended from Urban, Nordensvärd and Zhou, 2012.

The following sections will address the status and prospects of solar PV, as well as the politics and the user practices.

\subsection{Solar PV: status and prospects}

By 2015, seven of the top 10 solar PV manufacturers were Chinese: Trina Solar, Yingli Green Energy, Canadian Solar (Chinese-owned), Hanwha SolarOne, Jingko Solar, JA Solar and Rene Solar (Renewables, 2015). In recent years, China accounted for about $50-70 \%$ of 
This is the accepted version of a forthcoming article that will be published by Sage in Journal of Environment and Development: http://journals.sagepub.com/loi/jeda

Accepted version downloaded from SOAS Research Online under licence CC-BY-NC 4.0 International from: http://eprints.soas.ac.uk/24930/

global PV module production (REN21 2015: 48; NDRC, 2012). China has become the world's leading supplier of solar PV as in 2012 around 95\% of China's solar PV systems were manufactured for export (REN21, 2013). Today about $80 \%$ of all Chinese solar PV technology is being exported to developing countries, particularly to ASEAN countries. This is a direct result of the anti-dumping and anti-subsidy trade disputes between China and the EU / USA (Renewable Energy World, 2015). Domestically, China accounted for just under $20 \%$ of global installed PV capacity in late 2017 (WEC, 2017). See figure 2.

Figure 2: Share of cumulative installed solar PV capacity in 2016. Data from World Energy Council WEC, 2017.

\section{Installed capacity: solar PV}

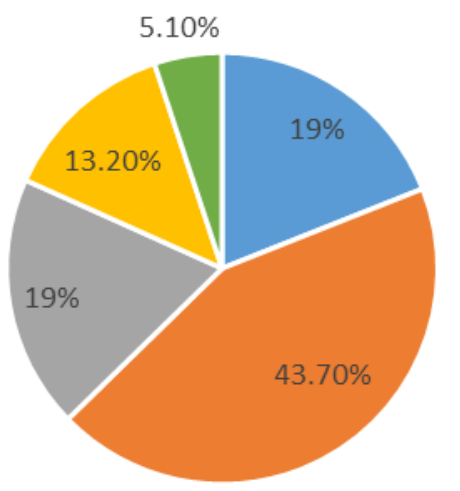

- China $\quad$ Europe $\quad$ Asia (excluding China) $\quad$ North America $\quad$ Rest of world

The domestic installed capacity is increasing as prices have fallen rapidly in recent years. In 2008 , the price of crystalline-silicon PV modules was about US $\$ 3.50-\$ 4.00$ per watt, by late 2011 prices were below the $\$ 1.00$ per watt mark for the first time, by 2013 they were about $\$ 0.50$ per watt and have since declined further. This is mainly due to a breakthrough in China in mastering purified silicon production technology. Interviewees report that "There is a rapid decline in solar PV prices, making it more competitive with fossil fuels, especially natural gas" (Representative of solar energy firm, interview, Beijing, January 2016).

In its early development, the Chinese government's renewable energy policies focused on the domestic installation of wind energy, while solar PV was for many years regarded as an export industry. For buyers, relatively high prices, a lack of government incentives and the difficulty of installing solar PV modules meant solar PV modules were not widely installed, especially for individual users. "Many potential consumers do not own or have access to roof space, and connectivity with the grid is technically and bureaucratically challenging" (Energy expert, interview, Beijing, January 2016). Most PV is used in ground-mounted, large-scale installations, for which financial incentives are particularly crucial. Yet, this is beginning to change.

China has a target of $100 \mathrm{GW}$ of solar PV capacity to be installed by 2020; a target that was increased several times as prior targets were exceeded, as energy experts report throughout the fieldwork. However, the installed capacity for solar PV was just over $43 \mathrm{GW}$ in late 2015 . It reached $78 \mathrm{GW}$ in late 2016, which is very close to the target. With costs falling and 
This is the accepted version of a forthcoming article that will be published by Sage in Journal of Environment and Development: http://journals.sagepub.com/loi/jeda

Accepted version downloaded from SOAS Research Online under licence CC-BY-NC 4.0 International from: http://eprints.soas.ac.uk/24930/

China's solar PV industry thriving many interviewees see in China the prospect of an important step forward in the large-scale diffusion of low carbon energy technologies worldwide.

\subsection{Solar PV: politics}

The most important state actors are the central government, the provincial government and the municipal governments. The state bureaucracy also plays a major role, such as NDRC and various ministries like MOST, MOFCOM, MIIT, MFA etc. The most relevant non-state actors are solar PV firms, both privately owned and SOEs, as well as the individual and industry-scale users of these technologies that contribute to its domestic use. Other non- state actors that play a key role are banks and civil society organisations.

The interviewees report that the main obstacles for the further expansion of the solar PV industry are the high up-front costs of solar PV; integration with the grid, including accessing the feed-in-tariff, which is more of a regulatory / legal challenge than a technical challenge; and that the public and industry regard PV as mainly being for buildings and factories, less for individual use by home-owners.

A representative from MOFCOM mentioned that: "The approach of the grid fits with the Chinese history of management which is very centrally planned. The industry has been driven not by the grid but by people focused on subsidies. The grids think of themselves as a ministry not a company. If they were divided into companies, it would sometimes be more efficient. There is therefore a need to reform the grid." (MOFCOM representative, interview, Beijing, October 2015).

The government regards solar as a strategic industry; hence the central government gives institutional and financial support, as do local governments. The Chinese government has supported research on solar PV, mainly for uses in space, since the 1950s. In the 1990s and early 2000s, the government promoted a number of PV industry development strategies, mainly focused on the production of solar consumer goods for export and remote rural electrification (Fischer 2012: 136). From 2004 to 2008, China's solar PV policy shifted to an "export-oriented growth stage" (Zhang, Andrews-Speed \& Ji, 2014: 906). As the government supported this burgeoning export industry, it invested in technology R\&D, covering almost every link in the solar PV manufacturing chain. Today, companies like Yingli Solar and Trina Solar have set up national PV key laboratories "with annual R\&D investment of 592 million RMB and 610 million RMB respectively between 2009 and 2012." (Sun, Zhi, Wang, Yao \& Su, 2014: 226).

It is clear that boosting solar PV manufacturing became part of core central government strategy and important for meeting its national climate and energy targets. China had a 12th Five-Year Plan for Solar Power Generation (2011 to 2015). This set targets to reduce the price of solar power and to increase the production of PV modules (Du 2012). China has also launched further incentive policies to boost PV market expansion, particularly to expand the PV output through feed-in-tariffs. Further, MOST has driven forward PV R\&D, with an average annual investment of around 500 million yuan (around US\$81 million) toward all segments of the manufacturing chain: Poly-Silicon, wafer, solar cells, PV modules, thin-film technology, energy storage, balance of system (BOS) components and system engineering as well as Concentrated Solar Power (Wang, Shu \& Lv 2013: 47-50). 
This is the accepted version of a forthcoming article that will be published by Sage in Journal of Environment and Development: http://journals.sagepub.com/loi/jeda

Accepted version downloaded from SOAS Research Online under licence CC-BY-NC 4.0 International from: http://eprints.soas.ac.uk/24930/

In the case of solar PV, other important actors are China's local governments, who often give greater preferential treatment to solar PV firms compared to other industries. This preferential treatment, according to Chen (2014: 11-12), includes: "free or low-cost loans, tax rebates, research grants, cheap land", as well as "energy subsidies and technological, infrastructure and personnel support." Furthermore, local governments typically supported indigenous PV producers by instructing local commercial banks to offer "bountiful loans" at low interest rates. One example is Jiangsu Province, home to Chinese SOE Suntech and to some "particularly aggressive solar development policies" (Zhang, Andrews-Speed and Ji, 2014: 907). Suntech received bank loans worth US $\$ 56$ million at the end of 2005 , but this amount had risen to US $\$ 3.7$ billion at the end of 2012, mainly due to municipal government's ability to order local state-owned banks to provide low-interest loans (Chen 2014: 11). Interviewees report the unequal distribution of different levels of tax breaks and other incentives on various levels of government, depending on different provincial and municipal governments and sometimes even depending on specific officials. "Different level of taxes, land concessions and infrastructure access, such as the accessibility to the port in Tianjin, enable individual provinces or municipalities to attract solar energy firms. Each provincial or municipal government has their own approach, it depends strongly on local government support." (Representative of Yingli Solar, interview, Tianjin, October 2015).

The relationships between non-state actors, most importantly solar PV firms and banks, with government authorities is very close in China. The financial crisis decreased solar PV exports, yet central government was keen to maintain high economic growth in the sector. In 2009, the Golden Sun programme for distributed solar PV was launched by MOST and the National Energy Administration (NEA). This massive government-supported investment boom between 2009 and 2011 resulted in even greater overcapacity of solar panel manufacturing by 2012. By this time Chinese production capacity of solar panels had reached $55 \mathrm{GW}$, representing around $150 \%$ of annual global consumption (Zhang et al, 2014: 909-10).

The consequent global decline in prices of solar PV modules caused a number of US and EU solar PV manufacturers to go bankrupt: between 2011 and 2012, Solyndra (USA), Q- Cells (Germany), BP Solar and others pulled out of the solar PV industry and others downscaled their operations, including Sharp (Japan) and First Solar (USA). In 2013 China's biggest solar panel manufacturing firm Suntech Power announced that it had defaulted on its debt, failing to pay US\$541 million worth of bonds. The interviewees report that Suntech, and its founder Shi Zhengrong had been frequently heralded as the vanguard of China's solar PV industry with considerable political support, particularly from the provincial government in Jiangsu. Interviewees suggested that there were several reasons for the decline of Suntech: pressure from local government to expand; Shi's own management style, external economic forces. Some interviewees suggest that the most immediate cause may have been Suntech's longterm contracts for the supply of polysilicon, which became a drain on the firm after its price fell dramatically in 2011 , thanks to breakthroughs in the production process. Yet, the fact that Suntech survived, albeit in a smaller form, shows how the pro-active state actively raises the level of government support behind the solar PV industry.

\subsection{Solar PV: practices, obstacles and trade-offs}


This is the accepted version of a forthcoming article that will be published by Sage in Journal of Environment and Development: http://journals.sagepub.com/loi/jeda

Accepted version downloaded from SOAS Research Online under licence CC-BY-NC 4.0 International from: http://eprints.soas.ac.uk/24930/

Despite rapid decreases in price, solar PV installations are still relatively expensive for private users, such as individual households. The following section of the paper assesses the practices, obstacles and trade-offs of solar PV in China and how they are being dealt with. Solar energy is considered as climate-friendly, environment-friendly and does not lead to adverse effects of the same scale or severity as other energy sources (e.g. displacement and resettlement of millions of people for large dams; nuclear waste, risk of nuclear accidents, nuclear health and safety; poor working conditions for coal miners and large contribution to climate change by fossil fuels). Hence, the trade-offs between the environmental, social and economic dimensions are rather limited.

Interviewees suggest that a major obstacle to the increased use of solar PV is the predominant use of fossil fuels, and particularly coal, and the importance they continue to play in China's energy mix. The heavy reliance on fossil fuels diminishes efforts towards a low carbon transition. Still, the IEA (2017) electricity figures for China show a moderate increase in renewables in recent years (more than $20 \%$ renewable energy in 2015), hence meeting official targets.

Other obstacles for the further diffusion of this technology include the limitations of roof-top space for solar PV, competition for land for various uses (including agricultural) vs land for ground-mounted PV installations. Our fieldwork shows that in urban areas, a common problem is the lack of privately-owned roof-space and the fact that much of the roof-space is shared, hence requiring the approval of a large number of neighbours in apartment blocks or high-rise buildings. The financial risks of privately-installed PV installations are therefore individualised, while the approval and decision-making process of allowing PV on roof-tops is collectivised. Even in mega-cities such as Shanghai, our fieldwork reveals that there seems to be little knowledge about low carbon energy, let al.one solar PV systems, among the public. Our fieldwork found that when the low carbon lifestyle advocate Ni Huan, the first person to install thin-film solar PV panels in Shanghai, aimed to install the systems at her home, she was confronted with social challenges such as her neighbour's safety concerns with regards to PV systems catching fire. It took her only two weeks to install thin-film solar PV modules in July 2014, yet before she could manage that she had to talk to her neighbours for 2-3 months and get the approval of the local committee as the apartment block's roof-top space is jointly owned. She concluded, that the biggest obstacle to private solar PV installation is the cost of legal challenges, while the cost of solar PV is falling (Ni Huan, interview, Shanghai, November 2015).

Yet, costs seem to be one of the main prohibiting factors for individual users: according to our fieldwork, thin-film PV systems, such as copper indium gallium selenide (CIGS) thin-film, cost about 24,000 RMB (US\$ 3,700) for $2 \mathrm{~kW}$, while prices for silicon-based PV systems have declined to below US\$ 0.5 per kW, hence $2 \mathrm{~kW}$ costing less than US\$1,000 in China. Outside China, PV prices are far more expensive. Interviewees complained that it takes a long time to pay back the investment: "Feed-in-tariffs are low, as is the electricity price, hence the payback period is 8-10 years." (Representative of solar energy firm, interview, Dezhou, December 2014). "The feed-in-tariff differs from province to province, but a typical feed-in-tariff for solar $P V$ is 0.2-0.3 Yuan/kWh plus 0.42 Yuan/kWh for the electricity price, so a total of 0.7-0.8 Yuan/kWh." ... "There is no easy financial route for individual users in the residential market to increase ownership of PV, as banks are not usually keen to provide loans or similar services for renewable energy. Bureaucratic and technical hurdles make grid 
This is the accepted version of a forthcoming article that will be published by Sage in Journal of Environment and Development: http://journals.sagepub.com/loi/jeda

Accepted version downloaded from SOAS Research Online under licence CC-BY-NC 4.0 International from: http://eprints.soas.ac.uk/24930/

connections to PV systems difficult and complex." (Energy expert, interview, Tianjin, October 2015).

For large-scale installations, solar companies reported that the main obstacle is the grid. It is very bureaucratic and lengthy to connect PV installations to the grid. Interviewees stress that this is not a technical issue, but a legal / regulatory and administrative issue. The grid companies have to send out their engineers, check that the PV installation is in accordance with the regulations and technical standards used in the grid area and they are sometimes reluctant to invest this additional time and effort.

At the same time, competition for land and various uses of land for ground-mounted PV installations may be a trade-off. This relates particularly to agricultural use of land. Our fieldwork found that in the rural areas of the municipality of Beijing, the Beijing Energy Association is piloting a programme which allows small-holder farmers to receive solar PV installations free of charge. After successful connection with the grid the farmers benefit from the feed-in-tariff. However, there is a major concern about the use of this agricultural land as the farmers would lose a part of their land to PV installations or attempt to "farm beneath the solar PV installations", which was mentioned as a suggestion in our fieldwork (Interview with NGO representative, Beijing, December 2014), but this is highly unlikely to work in practice due to a lack of understanding of agricultural practices by the project funders.

Another trade-off for solar PV is that environmental pollution and occupational health risks arise due to toxic chemicals being used in the production process of solar panels. Interviewees mention 'hidden environmental effects' of purportedly clean technologies, such as for silicon processing and purification for solar PV. The substances that are used are similar to those used in micro-electronics industries. However these are marginal effects compared to the large-scale and often much more serious environmental and health risks that other energy options entail.

\subsection{SWH: status and prospects}

The section above discussed solar PV, this section elaborates on SWH. SWH are a 'home grown' Chinese technology that is ubiquitous in China, particularly in rural areas, and that has developed from grass-roots levels to mass products with relatively little government support.

Annini, Duric, Gonzalez \& Perissinotto (2014:1) describe SWH as the "undiscussed protagonist" of a transition from fossil fuels to low carbon energy. China is the largest solar hot water market worldwide. SWH were first developed in the 1970s in China. In the 1980s China began to produce flat plate SWH that were based on technology transfer of a Canadian design (similar to the predominant design used in Europe today). However, the production was expensive and there were technical problems. In the 1990s, Chinese scientists at the Beijing Solar Energy Research Institute at Tsinghua University developed and patented the evacuated tube design (also called the vacuum tube): an example of indigenous, low-cost innovation. This follows a trend that we can also see in the wind energy sector, namely the emphasis on university-led R\&D for renewables at national level in China. Non-state actors such as SWH firms and universities and research institutions are therefore particularly important for this sector. R\&D in the evacuated tube design was heavily 
This is the accepted version of a forthcoming article that will be published by Sage in Journal of Environment and Development: http://journals.sagepub.com/loi/jeda

Accepted version downloaded from SOAS Research Online under licence CC-BY-NC 4.0 International from: http://eprints.soas.ac.uk/24930/

supported by the national government until it was commercialised in 1998. Himin Solar Energy Group, China's leader in SWH, was the key player for commercialising the product and scaling up the business. Today, leading firms, such as Himin, still cooperate with the Chinese Academy of Sciences (CAS) and universities for R\&D in SWH. This requires a skilled work force for developing cutting-edge innovation, in addition to a low-cost work force for production of SWH (Annini et al., 2014). Today 95\% of all the SWH in China are of the evacuated tube design, according to Hu, Pejun \& Wang (2012). It is estimated that Chinese firms hold $95 \%$ of the patents for core technologies of SWH worldwide (CGTI, 2009). This is being confirmed by the interviewees.

Figure 3: Share of the total installed capacity of solar water heating in operation by economic region in 2016.

\section{Installed capacity: solar water heaters}

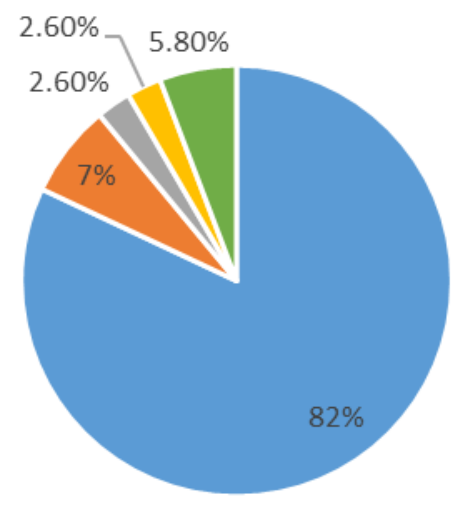

- China - Europe $\quad$ Asia (excluding China) - Latin America - Rest of world

Data from Weiss et al., 2017.

Today, Chinese SWH are predominantly produced for the domestic market, particularly in rural areas and small towns. Almost $65 \%$ of the world's installed solar water heater capacity was in China in 2009 (REN21, 2012). By 2016 this figure had reached over 80\%, meaning a total of 442 million square meters of SWH had been installed in China, according to Weiss, SporkDur and Mauthner (2017:53). See figure 3. In 2009 it was reported that over 30 million households used SWH households (CGTI, 2009), while calculations suggest that today over 75 million solar water heating systems are being used in China. It is estimated that more than 309.5 MW of solar thermal heating capacity is currently installed in China, which is reported to save about $86,000,000 \mathrm{t} \mathrm{CO}_{2}$ per annum. (Weiss et al, 2017:53). Interviewees point out that the "carbon savings of solar water heaters are more than the value of the entire current carbon trading system of China" (Representative of solar energy firm, interview, Dezhou, December 2014).

The interviewees are unanimous in suggesting that the potential market for SWH in China is huge. Today, about one million SWH are being manufactured every year (Hu et al., 2012), though regional variations exist, with Shandong having the highest penetration rate of $\mathrm{SWH}$, namely, about $20 \%$ of all households owning water heaters (Li, Song, Beresford \& Ma, 2011). Shandong province is also home to a solar water heater innovation cluster, which hosts the world's largest solar water heater firms. Interviewees suggest that this cluster has 
This is the accepted version of a forthcoming article that will be published by Sage in Journal of Environment and Development: http://journals.sagepub.com/loi/jeda

Accepted version downloaded from SOAS Research Online under licence CC-BY-NC 4.0 International from: http://eprints.soas.ac.uk/24930/

developed partly due to provincial and municipal government support, networks among innovative firms, good infrastructure links and the lack of cheap provincial fossil fuel resources.

The sector has seen a rapid increase over the last 15 years (Liu, Wang, Zhang \& Xue, 2010). It is estimated that growth rates for solar water heater annual output increased at about 2025\% each year between 2000 and 2010 (Hu et al., 2012). Figure 4 shows the accumulated installation of SWH and their growth rate. Interviewees point out that they see a further increase in the Chinese SWH market in the near to medium-term future.

Figure 4: Accumulated installation of SWH between 2005 and 2015, measured in MW.

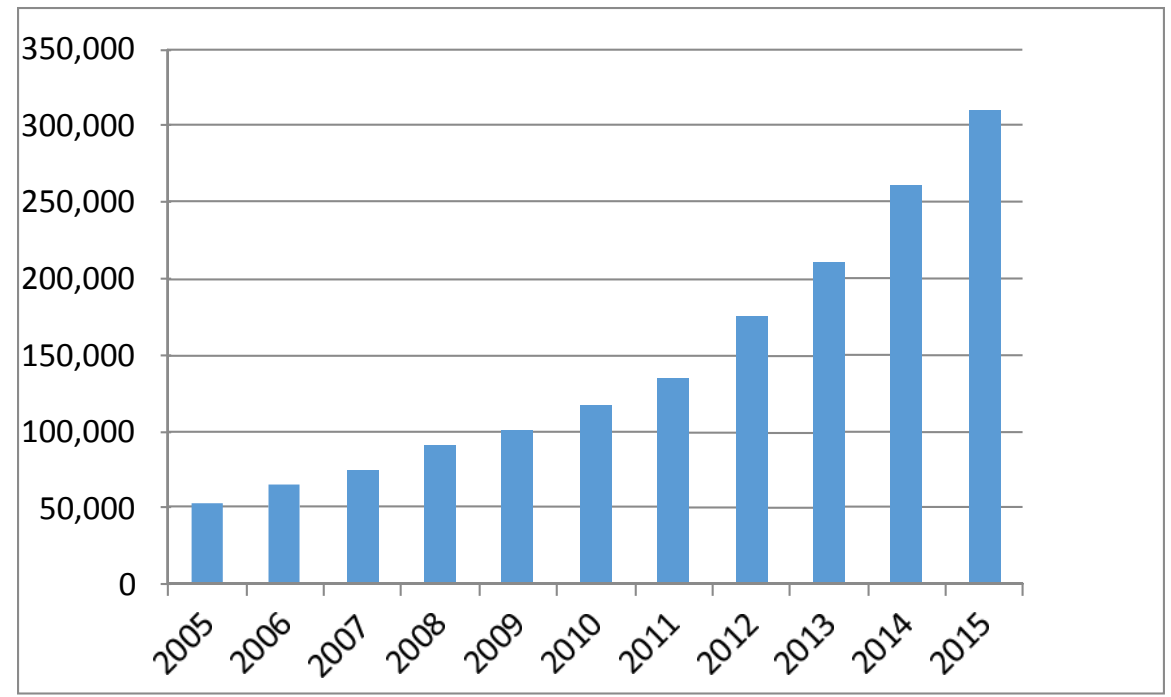

Calculated based on data from Weiss, Spork-Dur and Mauthner, 2017.

Our fieldwork found that experts estimate that there are about 3,000 solar water heater firms in China, of which about 1,800 are solar water heater manufacturers and the remaining 1,200 firms are component suppliers. Of these 3,000 firms, the top 10 firms account for more than a quarter of the Chinese solar water heater industry and about 30 firms are relatively large firms in terms of sales volume and production. Four firms are reported to have an annual sales volume of approximately 2 billion yuan (around US $\$ 326$ million), two firms have an annual sales volume of approximately $0.5-1$ billion yuan ( $\$ 81-\$ 162$ million) and more than 20 firms have an annual sales volume of approximately 100-500 million yuan ( $\$ 16-\$ 81$ million) (Hu et al. 2012). Both private firms and SOEs form the solar water heater industry.

There are several innovation clusters in the solar water heater industry, for example in Shandong, Jiangsu and Beijing ( $\mathrm{Hu}$ et al., 2012). China has introduced several national standards to guarantee the quality of SWH and has put the Chinese Committee for the Standardization of Solar Energy in charge of this process. Three product-testing centres exist in Beijing, Hubei and Yunnan, although some leading firms have their own testing centres. The State Administration of Quality Supervision, Inspection and Quarantine oversees the testing and it is estimated that about $80-93 \%$ of the tested SWH pass the standards test. There are also voluntary certification centres that certify the quality of the SWH and/or their impact on the environment (e.g. ISO 14001-type certifications). There is however a continuous problem with some small and medium enterprises (SMEs), particularly 
This is the accepted version of a forthcoming article that will be published by Sage in Journal of Environment and Development: http://journals.sagepub.com/loi/jeda

Accepted version downloaded from SOAS Research Online under licence CC-BY-NC 4.0 International from: http://eprints.soas.ac.uk/24930/

in rural areas, that have sub-standard production systems and outputs (Hu et al., 2012; Han et al., 2010). Interviewees highlight the importance of high-quality SWH and stress that "cheap copy-cat SWH can cause serious damage such as water damage to homes, breaking of frames and tubes." (Representative of Himin Solar, interview, Dezhou, December 2014).

Today, the solar water heater supply chain is complex, including manufacturing firms, component suppliers, service providers, distributors, utility firms and sales agents. The sector has increasingly become more efficient, thereby also decreasing costs per unit. According to interviewees, "a solar hot water heater costs a few thousand RMB, depending on quality and size." (Representative of solar energy firm, interview, Dezhou, December 2014).

In terms of costs, the SWH have higher upfront costs than electric hot water boilers or natural gas hot water heaters; however, they have minimal annual maintenance costs and lower annual costs than the other hot water heaters when compared by lifecycle analysis (Hu et al., 2012). The economic break-even point for SWH compared to electric water heaters is usually at around 3 years; afterwards electric heaters are far more expensive than solar heaters ( $\mathrm{Li}$ et al., 2011).

\subsection{SWH: politics}

SWH make an interesting case as they have relatively little stable national financing incentives since the evacuated tube design was commercialised in 1998 (although there was nationallevel support for R\&D before its commercialisation). There are few formal subsidies at the national level and there is a limited amount of industrial policy that supports the growth of the solar water heater industry. Unlike solar PV and wind energy, SWH have been developed mainly at the local level after their commercialisation without much central government support. However, between 1970s and the 1990s, central government initiatives played a key role for developing the cutting-edge evacuated tube design. These were mainly supply-side policies and subsidies provided by the state. Today, in the absence of much central government support, solar thermal firms are arguing for more government subsidies: "To be more profitable we need more subsidies from the government." (Representative of solar thermal firm, interview, Dezhou, December 2014).

Nevertheless, since the introduction of the Renewable Energy Law in 2006, there has been a rapid expansion of solar water heater installation across China. This is mainly due to two policy incentives:

First, since 2007 some provincial and municipal governments - including Hainan, Fujian, Jiangsu, Hebei, Henan, Shandong and Ningxia and cities like Shenzhen, Jinan, Rizhao, Yantai, Zibo, Qingdao, Xingtai, Qinhuangdao, Zhengzhou, Sanmenxia, Hohhot, Nanjing and Wuhan - have introduced a mandatory requirement to install SWH as part of every new building.

Second, another important policy is a payment of subsidies for SWH under the 2009 policy on "household appliances going to the countryside", which aims to increase the availability and use of SWH in rural areas with a subsidy equivalent to a reduction of $13 \%$ of the wholesale price (Hu et al., 2012). Solar energy experts and firm representatives stressed the 
This is the accepted version of a forthcoming article that will be published by Sage in Journal of Environment and Development: http://journals.sagepub.com/loi/jeda

Accepted version downloaded from SOAS Research Online under licence CC-BY-NC 4.0 International from: http://eprints.soas.ac.uk/24930/

importance of these two policies as the legislative and financial driving forces by provincial and municipal governments to support the SWH industry and technology uptake.

In addition, local provincial and municipal governments provide financial support to SWH firms, such as access to cheap land and tax rebates. SWH firms, both private and SOEs, therefore have strong links with local governments.

The fieldwork involved speaking to a focus group in Baoding, Hebei province, who were residents of new high-rise buildings that had SWH installed on a mandatory basis. The locals were very positive about the use of $\mathrm{SWH}$, praised the mandatory SWH requirements of the new buildings and the role of the local government in achieving these requirements, and discussed their motivations for supporting it such as "being environmentally-friendly", "supporting the local industry" and "cost-saving" etc (local users of $\mathrm{SWH}$, focus group discussion, Baoding, October 2015).

The NDRC's Medium and Long-Term Plan for Renewable Energy in China, which was issued in 2007 and covers plans up to the year 2020, mentions targets for SWH: a total heat collecting area of 300 million square metres to be installed by 2020, replacing 60 million tons of coal equivalent (tce). By 2015 a total of 442 million square meters of SWH had been installed in China (Weiss et al., 2017:53), thereby easily exceeding the initial targets for 2020 . Interestingly, SWH are mentioned less than solar PV or other renewables in more recent national policy documents. The $12^{\text {th }}$ and the $13^{\text {th }}$ Five Year Plans, covering the periods 20112015 and 2016-2020, do not seem to focus much on SWH. This might be due to the assumption that Chinese SWH are already a mature technology, widely commercialised and deployed for two decades.

Interestingly, fiscal or taxation incentives in China for the SWH industry is patchy or ad-hoc at best, yet solar hot water installation and sales have nevertheless increased rapidly in recent years, only driven by a large and rapidly expanding demand, particularly in the rural areas and in smaller towns. Interviewees argue that SWH meet the demand of millions of Chinese customers by offering good quality, high performance, but at a low cost.

The above section stressed the role of the state at the municipal and provincial level, not the national level. The pro-active, central state has therefore withdrawn from actively supporting the SWH industry, instead individual provincial and municipal governments have filled this gap at an ad-hoc and patchy basis. This 'fragmented authoritarianism' (Lema and Ruby, 2007) causes limits to growth for the SWH sector, yet at the same time is has enabled the sector to grow below the radar and avoid strict national scrutiny, but enjoys strong local support.

\subsection{SWH: practices, obstacles and trade-offs}

The above section presented the case of the flourishing solar water heater industry and the factors that have made it to a domestic, large-scale success, with provincial champions while the central government has been predominantly involved in the early stages of the technology development, not in the later stages. An important factor in this is demand successes. About 75 million solar water heater systems are estimated to be installed in China (Weiss et al., 2017:53), evidence that individual consumers can significantly drive forward the uptake and large-scale deployment of low carbon innovation. 
This is the accepted version of a forthcoming article that will be published by Sage in Journal of Environment and Development: http://journals.sagepub.com/loi/jeda

Accepted version downloaded from SOAS Research Online under licence CC-BY-NC 4.0 International from: http://eprints.soas.ac.uk/24930/

In the absence of centrally-administrated financial incentives for $\mathrm{SWH}$, interviewees stressed the importance of local employment creation. Dezhou, China's Solar Energy Valley, is also a proof that creating a local low carbon innovation cluster attracts a wide range of investments and the mushrooming of solar energy firms, in addition to local employments and tax revenues for the municipality. "In Dezhou alone, 50,000 people work in solar energy. Locals are very supportive of this industry." (Representative of Shandong province Development and Reform Commission, interview, December 2014).

Interviewees suggest that SWH are also based on China's natural endowments for solar energy. It reduces pressure during peak load and thereby contributes to energy security and opportunities for economic growth at the local and provincial level. At the grassroots level it is also suggested that end-users in China have in general a very positive attitude and high levels of public acceptance towards low carbon energy due to the general awareness of China's resource scarcity and the fact that solar energy provides employment in many regions in China (Li et al., 2011). Interviewees mentioned another reason for China's rapid rise in SWH, namely the relaxed building codes that enable setting up SWH on roofs without planning permission or other bureaucratic rules (contrary to solar PV), which depends on the discretion of local governments. However, our fieldwork finds that experts as well as users think that the most important argument for SWH is their low cost.

At the same time, solar water heating is culturally accepted as it has been practiced for many centuries in China. "SWH fit with the traditional practices of water heating in China. Before modern SWH existed, people in rural China filled dark buckets with water, put them on their roofs and waited until the sun heated up the water, so that people could have their baths or showers." (Energy researcher, interview, Beijing, January 2016). Modern SWHs are therefore in line with traditional, preferred practices of heating water in rural China. This is despite some disadvantages of $\mathrm{SWH}$, such as 1 . the limited volume of hot water that solar heaters can produce at any one time, 2. the time it takes to heat up new water once the first volume of hot water has been used, 3 . as solar radiation varies, the time for heating up water can take longer on cloudy days than on sunny days. Yet, none of this was mentioned as particularly inconvenient by the users of SWH in the focus group discussions or interviews, particularly as the low cost of SWH outweighs other minor disadvantages. An Interviewee from Himin confirms that "about half of our SWH products are sold to residential customers, both in rural and urban areas, and half to the public sector, such as to schools and hospitals." (Representative of Himin Solar, interview, Dezhou, December 2014).

The main obstacles for the development of SWH in China are limited central government support; the ad-hoc, patchy and fragmented approach to state support by some municipalities and provincial government authorities; quality issues with cheap copy-cat products from lowquality firms; the changing user practices required for using SWH over electric or gas boilers, although this seems to have a minimal effect in China. As with solar PV, more severe tradeoffs between environmental, social and economic dimensions are not occurring, unlike for other energy sources such as fossil fuels, nuclear power plants or large hydropower dams. State-actors at the national level have predominantly focussed on solar PV, while SWH has received little central government support over the two last decades. Yet, there has been a lot of support from local governments for SWH, including in Hainan, Fujian, Jiangsu, Hebei, Henan, Shandong and Ningxia and cities. 
This is the accepted version of a forthcoming article that will be published by Sage in Journal of Environment and Development: http://journals.sagepub.com/loi/jeda

Accepted version downloaded from SOAS Research Online under licence CC-BY-NC 4.0 International from: http://eprints.soas.ac.uk/24930/

\section{Discussion and conclusion}

This paper reviewed pathways towards the green economy in China by examining a case study on solar energy in China. The research analysed two different solar energy technologies, namely solar PV and SWH. It assessed the prospects, politics and practices of China's low carbon transitions in solar energy and how it is associated with different models of innovation, as well as addressing the role of the state, particularly central vs local government and its role in supporting innovation in solar energy.

Trade-offs between the environmental, social and economic dimensions are relatively minor as discussed above, but there are a series of obstacles that limit the further growth of the solar energy industry in China. Obstacles for the further growth of the solar PV industry in China are the inhibitive costs for individual consumers; the lack of roof-top space particularly in urban areas; the earlier reliance on the export market with overseas demand crashing following the global financial crisis and the trade disputes on anti-dumping prices; the bureaucratic and administrative hurdles for applying the feed-in-tariff that make it difficult for private customers to make use of it. Main obstacles for the further growth of the SWH industry in China are the absence of active central government support which means that SWH tend to be neither accounted for in official climate targets nor supported by recent central government finances or policy; and the ad-hoc, patchy and fragmented approach to state support by some municipalities and provincial government authorities.

The key actors that play a role are state agencies at varying levels, particularly from central government for solar PV (such as NDRC, MOST, MOFCOM), and at provincial and municipal level for SWH; solar firms and business associations; individual customers particularly for $\mathrm{SWH}$, whereas industrial large-scale customers play a stronger role for solar PV; research institutions and universities that support the R\&D of these technologies and to a limited extent also NGOs.

The paper found two very different approaches to solar energy. The solar PV industry in China is experiencing increased domestic growth, after many years of being mainly export- oriented. Despite recent declines in prices of solar PV panels, the industry still enjoys much political and financial support from the central government and local governments. This underpins the theories of a pro-active state and its importance for driving forward low carbon transitions and decarbonisation of economies.

SWH systems on the other side are a 'home grown' Chinese technology that is ubiquitous in China, particularly in rural areas, and that has developed from grass-roots levels to mass products with relatively little government support. More important than the state is the issue of demand success. With an estimated 75 million solar water heater systems currently installed in China, individual users have massively contributed to the deployment and uptake of this technology and the carbon savings equal more than those of the total current pilot carbon trading system in China.

We also found very different approaches to these two solar technologies by the state. For solar $\mathrm{PV}$, the pro-active state, in this case particularly central government authorities, have played and are playing an important role. This is visible in financial support, as well as policy support and organisational support. This does not exist as such for SWH. Some central government support existed up to the 1990s, as the technology matured this support was 
This is the accepted version of a forthcoming article that will be published by Sage in Journal of Environment and Development: http://journals.sagepub.com/loi/jeda

Accepted version downloaded from SOAS Research Online under licence CC-BY-NC 4.0 International from: http://eprints.soas.ac.uk/24930/

however withdrawn. Instead, municipal and provincial government authorities have partly replaced some central government functions by providing some support, albeit rather patchy and ad-hoc without much continuity or replicability across municipalities/provinces. This has resulted in a couple of favourable policies in some provinces and municipalities and some financial support for SWH firms, however nothing at the scale or consistency of central government support. Instead, solar water heater firms depend on local demand success and the favour of mass consumers.

Still, both the solar PV and the solar water heater technologies and industries are highly commercialised and market-ready in China. Hence both technologies are success stories, albeit with very different characteristics and dynamics.

With regards to recommendations for scaling up low carbon transitions in solar energy, the solar PV industry and PV policy could benefit from learning how the solar water heater industry grew rapidly and continuously in recent years in the domestic market, how domestic demand was created and how this could be supported and improved in the solar PV sector. Expanding domestically requires achieving lower prices, or introducing higher subsidies, that could make solar PV more affordable for individual consumers and hence the mass market. Access to the feed-in-tariff would also need to be simplified. At the moment the focus of the government is too much on growing the scale of the domestic PV market by growing the size of groundmounted, industrial-scale installations. The experience from the Chinese solar water heater industry however indicates that there is not necessarily a need for the central government to drive industrial-scale installations, but that the key to success are lower prices and easy installation without much bureaucracy to enable individual consumers to purchase and use their own solar energy installations. This needs targeted subsidy programmes and reduction of bureaucratic and technical hurdles, particularly in the rural areas where roof-top spaces are more readily available.

The solar water heater sector provides evidence of a less tightly governed sector that mainly thrives due to individual consumer choices. Representatives of solar water heating firms stress the importance of SWH for a Chinese low carbon transition and for achieving national climate change mitigation targets and thereby argue for more financial and policy support from central government.

In conclusion, lessons can be learned from both technologies and their politics and practices to increase the chances for wider, successful low carbon transitions in China's energy sector.

\section{Acknowledgements:}

The authors would like to thank the UK Economics and Social Research Council ESRC for funding the project "Low carbon innovation in China: Prospects, Politics and Practice", (reference ES/K006002/1), the National Science Foundation of China (Grant No. 71573152) and the Volkswagen Foundation, Riksbankens Jubileumsfond and Wellcome Trust for funding the project "Green Transformations in the global South (GreeTS)". The authors are grateful to everyone who contributed to these projects. Thanks to four anonymous reviewers and Markus Lederer and Linda Wallbott for comments on an earlier version of the paper. 
This is the accepted version of a forthcoming article that will be published by Sage in Journal of Environment and Development: http://journals.sagepub.com/loi/jeda

Accepted version downloaded from SOAS Research Online under licence CC-BY-NC 4.0 International from: http://eprints.soas.ac.uk/24930/

\section{References:}

Annini, A.; Duric D.; Gonzalez, D.; and Perissinotto G 2014 "SWH Cluster in China: The beginning of the innovative era?" Grenoble Ecole de Management \& Lab-Center for Competitiveness

Beeson, M. (2010). The Coming of Environmental Authoritarianism. Environmental Politics, 19(2), 276-294.

Bloomberg News 2013 "China's Spending on Renewable Energy May Total 1.8 Trillion Yuan," July $30^{\text {th }}$. Available at: http://www.bloomberg.com/news/2013-07-30/china-s- spending-onrenewable-energy-may-total-1-8-trillion-yuan.html (Accessed August 7, 2014)

Chen, G. 2014, 'China's Solar PV Manufacture and Subsidies - From the Perspective of State Capitalism'. Paper for Green Asia Conference in Copenhagen.

China Green Tech Initiative (2011) China Green Tech Report 2011, Beijing: CGTI.

Du, J. 2012, "China's domestic solar market to expand", China Daily, February 25.

Fischer, D. (2012): 'Challenges of low carbon technology diffusion: insights from shifts in China's photovoltaic industry development', Innovation and Development 2 (1), 131-146

Gilley, B., 2017. Local Governance Pathways to Decarbonization in China and India, China Quarterly, Vol. 231: 728-748.

Gilley, B. (2012). Authoritarian Environmentalism and China's Response to Climate Change. Environmental Politics, 21(2), 287-307.

Han, J.Y., Mol, A.P.J., Lu., Y.L., 2010. SWH in China: A new day dawning. Energy Policy, Vol.38 (2010) 383-391.

Held, D., Roger, C., \& Nag, E.-M. (2013). Editors' Introduction: Climate Governance in the Developing World. In D. Held, C. Roger \& E.-M. Nag (Eds.), Climate Governance in the Developing World (pp. 1-28). Cambridge: Polity.

Hu, R., Peijun, S and Wang, Z. 2012, "An overview of the development of solar water heater industry in China," Energy Policy 51:C, pp.46-51

IEA (2017), Energy Statistics, IEA. https://www.iea.org/statistics/

Lederer, M., Walbott, L., Bauer, S., forthcoming. Tracing sustainability transformations in the Global South: an analytical framework to capture national Green Economy practices. To be submitted to the Journal of Environment and Development.

Lema, A. and Ruby, K., 2007. Between fragmented authoritarianism and policy coordination: Creating a Chinese market for wind energy. Energy Policy, Vol.35(7): 3879-3890

Lewis, J.I., 2013. Green Innovation in China: China's Wind Power Industry and the Global Transition to a Low carbon Economy. New York: Columbia University Press, 2013.

Li, W., Song, G., Beresford, M., Ma, B., et al. 2011. China's transition to green energy systems: The economics of home SWH and their popularization in Dezhou city. Energy Policy, Vol. 39 (2011): 5909-5919.

Liu, L-G., Wang, Z-X., Zhang, H-Q., Y.-C. Xue (2010) 'Solar energy development in China-A review', Renewable and Sustainable Energy Reviews 14(1):301-311. 
This is the accepted version of a forthcoming article that will be published by Sage in Journal of Environment and Development: http://journals.sagepub.com/loi/jeda

Accepted version downloaded from SOAS Research Online under licence CC-BY-NC 4.0 International from: http://eprints.soas.ac.uk/24930/

Miles, M. B., \& Huberman, A. M. (1994). Qualitative data analysis: An expanded sourcebook. Sage.

NDRC 2012, $12^{\text {th }}$ Five Year Plan for the Solar Photovoltaic Industry. NDRC.

Ockwell, D. and Mallett, A. (eds.) 2012, Low Carbon Technology Transfer: From Rhetoric to Reality. Routledge, Abingdon.

REN21 2012, Renewables 2011, Global Status Report

REN21 2013, Renewables 2012, Global Status Report

REN21 2017, Renewables 2017, Global Status Report

Reuters, 2017. China to plow $\$ 361$ billion into renewable fuel by 2020. http://uk.reuters.com/article/us-china-energy-renewables/china-to-plow-361-billion-intorenewable-fuel-by-2020-idUKKBN14P06P

Saviotti P. 2005. On the co-evolution of technologies and institutions. In Towards Environment Innovation Systems, Weber M, Hemmelskamp J (eds). Springer: Berlin; 9-31.

Schreurs, M. A. (2011). Climate Change Politics in an Authoritarian State: The Ambivalent Case of China. In J. S. Dryzek, R. B. Norgaard \& D. Schlosberg (Eds.), The Oxford Handbook of Climate Change and Society (pp. 449-463). New York: Oxford University Press.

Stavins, R. N. (2014), 'Chinese and US climate interests are converging', chinadialogue May 6, available at: https://www.chinadialogue.net/blog/6952-Chinese-and-US-climate-interestsare-converging/en Accessed August 26, 2014

Sun, H., Zhi, Q., Wang, Y., Yao, Q. and Su, J. 2014, "China's solar photovoltaic industry development: The status quo, problems and approaches" Applied Energy 118, pp.221-230

UNEP, United Nations Environment Programme. (2011) Towards a Green Economy:

Pathways to Sustainable Development and Poverty Eradication. http://web.unep.org/greeneconomy/sites/unep.org.greeneconomy/files/field/image/green ec onomyreport final dec2011.pdf.

Urban, F., Nordensvärd, J., Zhou, Y., 2012. Key actors and their motives for wind energy innovation in China. Innovation and Development, Vol.2(1): 111-130.

Urban, F., 2018. China's rise: Challenging the North-South technology transfer paradigm for climate change mitigation and low carbon energy. Energy Policy, 113(2018), doi: 10.1016/j.enpol.2017.11.007

Wang, C. and Liu, W.L., 2017. Low Carbon Urban Development in China: Policies and Practices in: Sternfeld, E., 2017. Routledge Handbook of Environmental Policy in China, Taylor \& Francis, Oxon.

Wang, Shu and Lv 2013, China: PV Technology and Prospects in Photovoltaic Power Systems Programme: Annual Report 2013. IEA, pp.44-51

Wang, F., Yin, H., and Li, S. 2010. China's renewable energy policy: Commitments and challenges. Energy Policy, 38(4), pp. 1872-1878.

Watson, J., Byrne, R., Ockwell, D. and Stua, M. 2014, "Lessons from China: building technological capabilities for low carbon technology transfer and development" Climatic Change May, pp.1-13 
This is the accepted version of a forthcoming article that will be published by Sage in Journal of Environment and Development: http://journals.sagepub.com/loi/jeda

Accepted version downloaded from SOAS Research Online under licence CC-BY-NC 4.0 International from: http://eprints.soas.ac.uk/24930/

Weiss, W., Spork-Dur, M. and Mauthner, F. 2017. Solar Heat Worldwide: 2017. http://www.iea-shc.org/data/sites/1/publications/Solar-Heat-Worldwide-2017.pdf

World Bank, 2017. Data. https://data.worldbank.org/

World Energy Council WEC, 2017. Solar energy data. https://www.worldenergy.org/data/resources/resource/solar/

Wurster, S. (2013) Compating ecological sustainability in autocracies and democracies. Contemporary Politics, 19(1), 76-93.

Yin, R. K., 2003. Applications of case study research (applied social research Methods). Series, 4th edn. Thousand Oaks: Sage Publications.

Zhang, F., and Sims Gallagher, J., 2016. Innovation and technology transfer through global value chains: Evidence from China's PV industry. Energy Policy 94 (2016): 191-203.

Zhang, S., Andrews-Speed, P., Ji, M. 2014, "The erratic path of the low-carbon transition in China: Evolution of solar PV policy” Energy Policy 67, pp.903-912 